\title{
咀嚼機能における咬合面形態の恋化と食物動態の関連性について
}

\author{
木戸寿明, 渡部厚史, 河野正司, 斎藤 彰 \\ 新潟大学歯学部㐘科補緅学第 1 講座 (主任：河野 正司教授)
}

〔受付: 平成 7 年 3 月 31 日]

\section{Relationship between behavior of food and occlusal configuration on masticatory function}

\author{
Toshiaki Kido, Atsushi Watabe, Shoji Kohno and Akira Saitoh \\ Niigata University, School of Dentistry. Department of Removable Prosthodontics.
}

(Director: Prof. Shoji Kohno)

[Recieved: March 31, 1995.]

Key Words: masticatory function, food behavior, occlusal configuration, Squeezing Room

\begin{abstract}
Mastication consists of a series of movement that co-activates upper and lower teeth and the soft tissues of the mouth in order to crash food and form swallowable food bolus. To comprehend masticatory function, it is essential to understand food behavior as related to the occlusal surface and its adjacent structures; but there are almost no reports available about it.

The purpose of this study was to observe food behavior following food crushing and consider the association between food behavior and occlusal configuration.

We designed a new method to estimating food behavior. Peanuts which were chewed were gathered separately from buccal side and lingual side after varying numbers of chewing strokes, and then measured the amount and the degree of crushing of each one. As subjects, four young adults with normal occlusion and no experience of dental treatment were selected. The results were as follows:

1. As mastication proceeded, the amount of broken down peanuts on the buccal side decreased significantly, and those on the lingual side increased gradually.

2 . The degree of crushing were higher on the lingual side than on the buccal side.

Recently it was stated that the "Squeezing Room", which exist upper first molar , plays an important role concerning food crushing. It is speculated that one of the factors regulating food behavior is the "Squeezing Room". To study this speculation, we examined food behavior using two experimental telescopic crowns. One was casted with usual molar anatomy whilst the other one without buccal cusps. Comparing food behavior with these two crowns enable us to imply the functional signification of the "Squeezing Room" on mastication.
\end{abstract}

抄録 咀嚼運動は, 上下顎の対合する歯と, 口腔周囲軟組織との協調運動により, 食物を粉砕し, 口腔内 に取り込み, 嚥下可能な食塊の形成を行う一連の運動であり, 咬合面周囲での食物の動態を把握すること は咀嚼機能を理解する上で不可欠なことである。そこで本研究では咀嚼中の食物の粉砕に伴う動態を把握 するとともに，その動態と咬合面形態との関連性を検討することを目的とした.

食物動態を測定するために新たな方法を考案した. すなわち, 被験食品としてピーナッッを用い, 規定 
回数咀嚼させた後, 䫏側に貯留するピーナッツと, 舌側に貯留するピーナッツを別々に回収し, その各々 の重量と，粉砕度について測定する方法である。その結果，煩・舌側貯留率に関しては咀嚼の進行に伴い 煩側貯留率は順次減少し, 逆に舌側は増加すること, 更に, 粉砕度に関してはいずれの咀嚼回数において も煩側よりも舌側が高いことが判明した。

最近，機能運動中の上顎第 1 大臼歯に存在する圧搾空間において食物の圧搾，粉砕が行われると主張さ れている．この考えに立脚すると，ピーナッツの動態を規定する因子の一つとして圧搾空間の機能が推測 される。そこで，実験的に天然歯を模倣した咬合面と煩側咬頭を削除した咬合面で食物動態の比較検討を 行った，その結果，前者に比べ，後者では煩側貯留率が増加するとともにその中に占める小さな粒子の割 合が増加する傾向が認められ，圧搾空間の機能的意義の一端を窥い知ることができた.

\section{I. 緒言}

咀嚼は顎口腔の主要な機能の一つであり, 咀嚼機能を 評価する方法が種々考案されている．その中でも理論的 に妥当性が認められ，広く用いられているものが食品の 粉砕度を指標として評価する篩分法 ${ }^{1 ， 2)}$ であり，これま で主に粉砕度と咬合面形態，咬合接触関係との関連性が 報告され，それらの咀嚼における重要性が述べられてき た ${ }^{3)}$.

ところで, 咀嚼運動は上下顎の対合する歯と, 舌, 煩 粘膜などの口腔周囲軟組織との協調運動により, 食物を 粉砕し，口腔内に取り込み，器下可能な食塊の形成を行 う一連の運動といえる。この咀嚼運動の過程における食 物の粉砕度のみならず，咬合面周囲での食物の動態を把 握することは, 咀嚼機能を理解する上で不可欠なことで ある。しかしその様相については未だ不明な点が多く， さらに食物の動態と咬合面形態との関連性についての報 告はほとんどない.

そこで本研究では, 正常者における咀嚼中の食物の動 態について明らかにすると共に，その動態と咬合面形態 との関連性として, 機能運動中に出現する咬合面間の対 合間隙の形態に着目し，その形態と食物動態との関係を 検討した。ささに，正常者で得られた対合間隙の特徴の 機能的意義を確証するための一環として，実験的に咬合 面の形態を変化させ，形態変化が食物動態に及ほす影響 を確認することを目的とした.

\section{II. 実験方法}

\section{1. 被験者}

歯に修復物が存在せず，第 1 大臼歯の近遠心的関係が Angle I 級の被験者 4 名（男子 3 名，女子 1 名）とした. また，上顎第 1 大臼歯に歯冠修復が必要な成人男子 1 名 について, コーヌステレスコープクラウンにて歯冠修復
を施し，この外冠を，天然歯を模倣した咬合面を有する ものと, 煩側咬頭を削除したものの 2 種類製作し, 外冠 を交換することによる形態の変化が食物動態に及ぼす影 響を評価した。

\section{2. 食物動態の評価}

食物動態を把握する手段として，ピーナッツ咀嚼を一 定回数行わせ, そのときの粉砕ピーナッツ粒の㚘側貯留 量と舌側貯留量及び粒子の大きさの変化から推定する方 法を新たに考案した. すなわち，ピーナッッ $3 \mathrm{~g}$ を規定 回数咀嚼させ，鯃下しないように咬頭嵌合位で閉口状態 を保たせ，㚘側に貯留しているものを術者が口腔内より 採取する. その後，舌側に貯留したものを吐き出しても らうことにより㚘側, 舌側それぞれに貯留したピーナッ ツを別々に回収する。さらに各々のピーナッツを $10 \mathrm{mesh}$ 篩にて篩分し，篩上に残留する粒子を回収する 方法である.

この方法により全回収重量に対する煩舌側各々に貯留 したピーナッツ粒子の重量の割合を貯留率，さらに各貯 留重量に占める $10 \mathrm{mesh}$ 篩を通過した小さな粒子の割合 を粉砕度と定義し，食物の動態を把握した。なお，咬合 面上に残留したものは舌側に貯留したものとした。

また，規定咀嚼回数は5回，10回，20回とした.

\section{III. 結 果}

\section{1.天然歯列における食物動態}

被験者 4 名計 8 側について 3 回ずつ測定して，合計 24 例のデータを得た。㚘頁側および舌側のピーナッツ貯留率 の平均値と標準偏差を規定回数別に表示したものが図 1 である．㚘舌側別に貯留率の推移を観察すると，頬側貯 留率は 5 回咀嚼時 $45.6 \%, 10$ 回咀嚼時 $41.5 \%, 20$ 回咀嚼 時 $31.4 \%$ と, 咀嚼の進行に伴い順次減少し，逆に舌側貯 留量は 5 回咀嚼時 $54.4 \%, 10$ 回咀嚼時 $58.5 \%, 20$ 回咀嚼 時 $68.6 \%$ と, 増加傾向を示していた。 


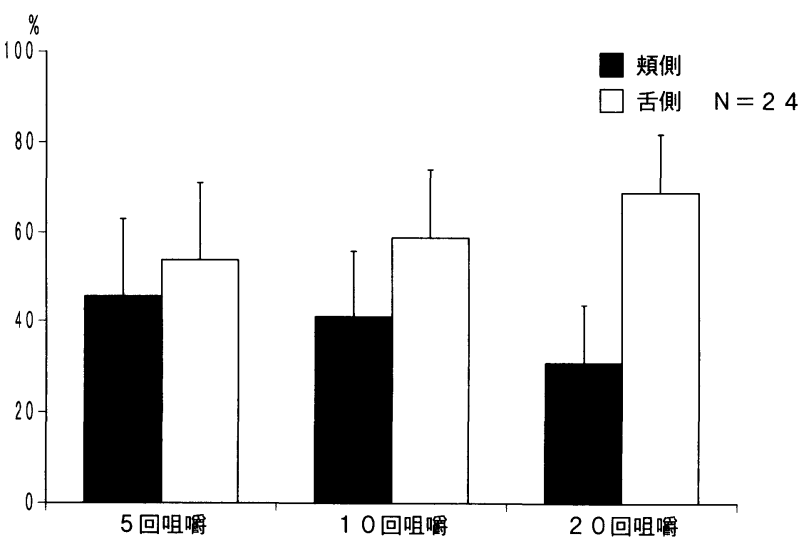

図 1 正常者 4 名 8 側のピーナツ㚘真・側貯留 率の平均值

Fig. 1 The average of percentage of the amount of peanuts on buccal and lingual side concerning 8 chewing sides of 4 normal subjects.

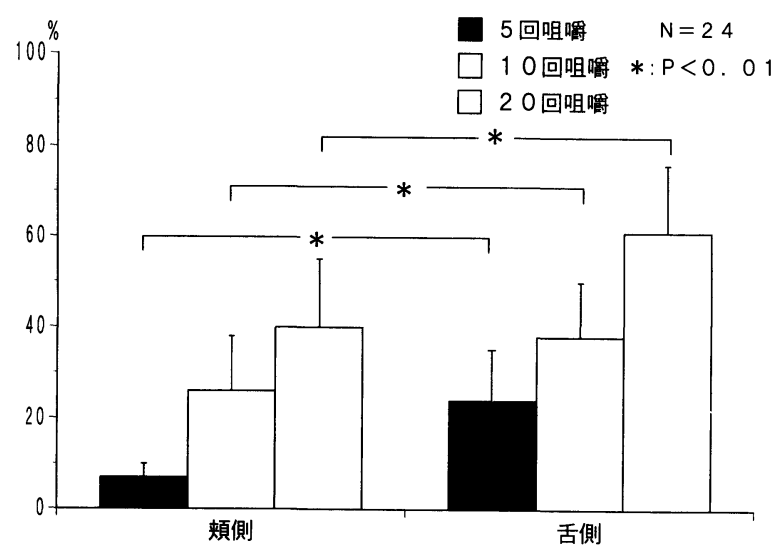

図 2 㚘頁・側貯留の粉砕度

Fig. 2 The degree of crushing on buccal and lingual side.

次に, 粉砕度に関して図 2 に示す. 5 回咀嚼において 煩側 $7.0 \%$, 舌側 $23.6 \%, 10$ 回咀嚼煩側 $25.5 \%$, 舌側 $38.2 \%$, 20 回咀嚼㚘側 $40.1 \%$, 舌側 $60.9 \%$ と, いずれの咀嚼回数 においても煩側と舌側の粉砕度に統計学的に有意差が認 められ, 煩側よりも舌側に貯留するピーナッツの方が粉 砕度が高い結果となった。

\section{2. 咬合面の変化と食物動態}

天然歯を模倣した咬合面と, 煩側咬頭を削除した咬合 面について，1例における変化を比較した際の煩・舌側 貯留率を図 3 に, 粉砕度を図 4 に示す. 両者とも正常例 の 4 被験者と同様の傾向を呈しているが，この両者間で 比較すると, 各咀嚼回数における煩 - 舌側貯留率の比率
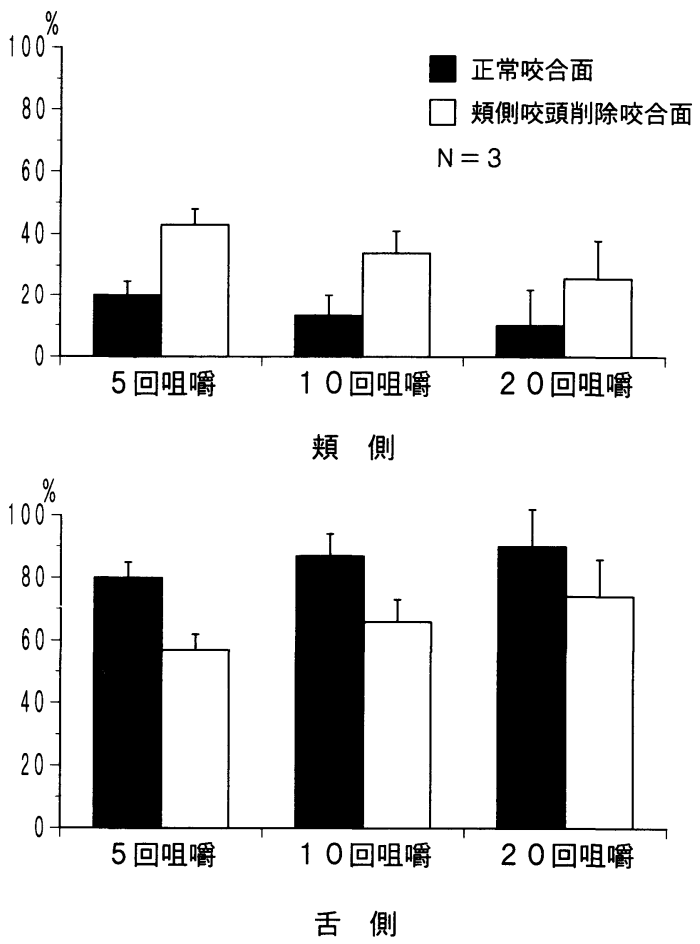

図 3 咬合面形態を変化させた場合における 煩・舌側貯留率の比較

Fig. 3 Comparison of the percentage of the amount of peanuts on buccal and lingual side between the two crowns.

が変化していること, さらに，粉砕度が煩側咬頭を削除 した咬合面では増加する傾向があった．例数が少ないた め, 統計学的な有意差が出るには至らなかったが, 被験 者は煩側咬頭を削除した咬合面を装着した場合,「ピー ナッツを舌側にまとめにくい」という感想を述べてい た.

\section{IV. 考察}

\section{1. 研究方法について}

従来の篩分法 ${ }^{2)}$ では, 口腔内で粉砕されたピーナツを まとめて回収していたが, 今回, 破砕により生じる食物 の動態を把握する目的で, 煩舌側に貯留するピーナッツ を別々に回収した。この方法により，ピーナッツ粒子の 煩舌的な流れと, 各々の粉砕度に関して定量的に評価す ることが可能となった。

\section{2. 実験結果について}

1)天然歯列の食物動態について

今回の測定の結果，健常者での食物動態の特徴として, 


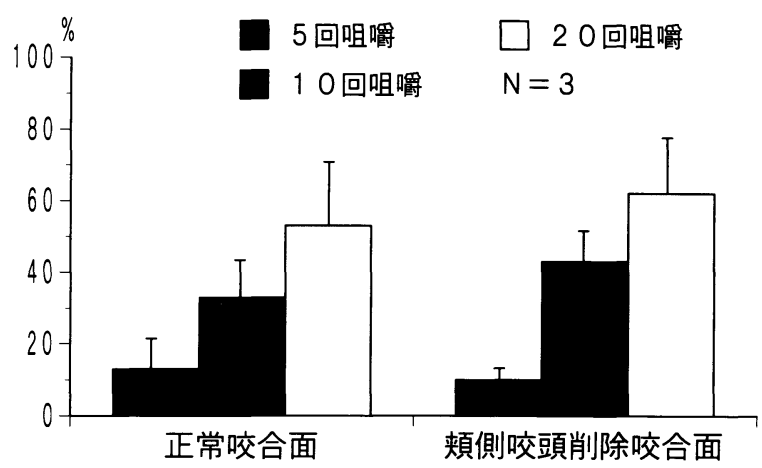

頼 側

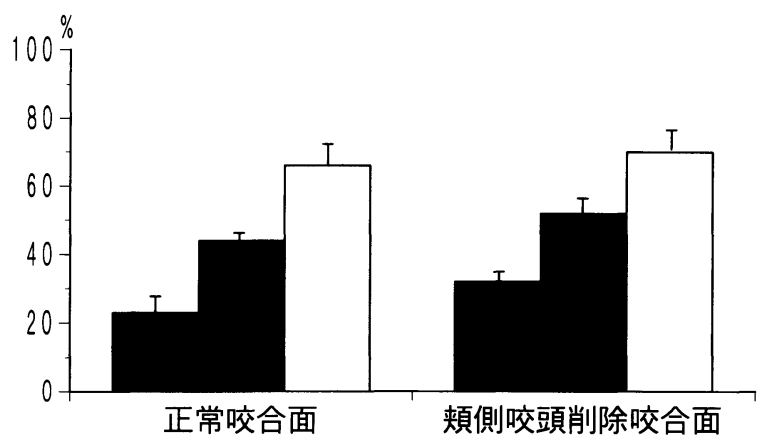

舌 側

図 4 咬合面形態を変化させた場合における粉 砕度の差異

Fig. 4 The difference of the degree of crushing between the two crowns.

咀嚼の進行に伴い頬側貯留率は順次減少し, 舌側貯留率 は逆に増加する。さらにその粉砕度は舌側の方が頪側よ りも高いということが明らかとなった。食品の粉砕度に 主眼が置かれた咀嚼の研究は数多く行われてきたが，そ の動態は粉砕に伴い特徴的な様相を呈していたことにな る. 食物の粉砕度が嚥下を規定する因子であるかどうか は議論の残るところではあるが4), 食物の粉砕と, 粉砕 された食物粒の口腔内への取り込みという行動は咀嚼の 過程に不可欠であることを考えると，観察された食物の 動態は合目的性を有していると言えるのではないだろう か.

2)咬合面形態と食物動態の関連性

最近, 咀嚼時に上顎第 1 大臼歯と, 下顎臼歯の咬合面 間には，圧搾空間が存在しており，咬頭嵌合位への噛み 込み過程において，この空間の中で食片が圧搾，粉砕さ れていることが主張されている ${ }^{5)}$.この最近の考えに立 って正常者における食物動態の特徵と, 咬合面形態との 関連性を検討してみる。

上下顎咬合面間にピーナッツが介在した時，圧搾空間
よりも䫏側あるいは舌側に存在する部分は破砕されると そのまま大きな粒子として煩舌側に流れる。一方, 圧搾 空間内に取り込まれた部分は閉口するに従い粉砕され る.この圧搾空間は近心舌側に開放されていることから， 粉砕されたピーナッツ粒子は舌側へ送り込まれる。その 結果, 舌側に貯留するピーナッツは粉砕度が高くなるの ではないだろうか.さらに, Manlyら ${ }^{2)}$ は, ピーナッツ 咀嚼の過程においては大きな粒子が選択的に粉砕される ことを確認している. 従って，すでに十分粉砕されたピ 一ナッツが咬合面上に乗った場合には，粉砕を受けなく ともそのまま圧搾空間を通り, 舌側へ送り込まれる機構 になっているのではという仮説が成り立つかもしれな い.

一方，コーヌステレスコープクラウンの咬合面形態を 変化させた 1 例について見ると, 䫏側貯留率が増加し, 㚘側に貯留するピーナッツに占める10mesh以下の小さ な粒子の割合が増加している. すなわち煩側咬頭を削除 することにより，近心舌側方向にのみ開放されていた空 間が，頬側方向にも大きく開放されたため，ピーナッッ の流れが変化し, 煩側方向に, しかも小さな粒子が多く 流れた結果であると推測できる，従来非機能咬頭と呼ば れている上顎煩側咬頭であるが, 食物の固有口腔内への 誘導という面で機能を果たしているのではないだろう か. ただし，今回は被験者が1名であり，例数も少ない ため, 推測の域を出ないのが現状である.

\section{3. 今後の課題}

食物の動態に関して，その動態を規定する因子として 咬合面に着目して検討を加えたが，他の生体の因子に関 しても検討の必要性がある.

さらに，圧搾空間とその機能に関し，煩側咬頭を削除 した咬合面と比較することにより機能的意義の一端を窥 い知ることができたが, 真の意味での機能的意義を確立 するためには更なる検証が必要である，そして他の歯種 に形成される間隙をも含めて検討しなければならない.

咀嚼の目的に添った食物動態を把握し，それを規定し ている生体側の因子が解明できれば，咀嚼に有利な顎口 腔系の形態と機能を決定できるのではないだろうか.

\section{V. 結 論}

1. Angle I 級の正常者の食物動態を測定した結果, 㚘舌・側への貯留率は咀嚼の進行に伴い頬側は順次 減少し, 舌側は増加した。粉砕度は, 各規定咀嚼回 数において，煩側よりも舌側が高かった。

2. 食物の動態を規定する因子の一つとして, 機能運動 
時に咬合面上に形成される圧搾空間の機能が考えら れた。

3. 実験的に煩側咬頭を削除すると, 食物動態は変化し て㚘側貯留率が増加し, 圧搾空間の機能的意義の一 端を知ることができた。

\section{文献}

1 ）石原寿郎：篩分法による咀嚼能率の研究, 口病誌, 22 : 207-255, 1959.
2) Manly, R. S . and Braley, L. C.: Masticatory Performance and Efficiency. J Dent Res, 39 : 448-462, 1950.

3 ）平沼謙二：咬合面積並びにその咀嚼効率に及ぼす影 響，補緅誌，1:17-36, 1957.

4 ) Lucas, P. W., and Luke, D. A.: Is food particle size a criterion for the initiation of swallowing?, J Oral Rehabil, $13: 127-136,1986$.

5 ）渡部厚史：側方滑走運動による上下顎大臼歯間の接 触間隙の変化, 補綴誌, $39: 517-529,1995$. 